\title{
Utilization of Slags from Foundry Process
}

\author{
Alena Pribulováa*, Peter Futáša, Marianna Bartošováa , Jozef Petrík ${ }^{a}$ \\ aTechnical University of Košice, Faculty of Materials, Metallurgy and Recycling, Letná 9, Košice, Slovakia \\ *e-mail: alena.pribulova@tuke.sk
}

Received: 10 October 2017/Accepted: 10 December 2017/Published online: 31 January 2018

This article is published with open access at AGH University of Science and Technology

\begin{abstract}
The melting of steel or cast iron is one step of the foundry process. The foundry industry uses different types of furnaces, and metallurgical slags are products of the pyrometallurgical processes defecting in these furnaces. Furnace slag is a non-metallic by-product that consists primarily of silicates, alumina silicates, and calcium-alumina-silicates. As a by-product of the melting process, furnace slags vary considerably in form depending on the melted metal furnace types, and slag cooling method used. Most quantity of slags from the foundry processes are created in a cupola furnace that is used for cast iron production. An electric arc furnace is usually used for steel production, but it can be used for cast iron production as well. Universal use features an electric induction furnace. Slags from the melting processes in a foundry can be in the form of gravel, or the slag from a cupola furnace can be granulated. The utilization of slags from foundry processes is very delimited in Slovakia because of their quantity. This article deals with the possibility of using foundry slag as a binder in civil engineering. A basic property of a binder in civil engineering is its hydraulicity, which can be given by compression strength. Four metallurgical slags were tested. The values of the compressive strength of the slags were low, but addition cement to the slags resulted in a strong increase in the value of the compressive strength.
\end{abstract}

\section{Keywords:}

melting, metallurgical furnace, slag, hydraulicity, compressive strength

\section{INTRODUCTION}

Slags are produced in very large amounts in the pyrometallurgical process and are huge sources of waste if not properly recycled or utilized. With the rapid growth of industrialization, the available land for land-filling large quantities of metallurgical slags is reducing all over the world; correspondingly, the disposal costs become increasingly higher. The global warming effect and natural resource saving are the general environmental topics nowadays. In addition, land filled with waste materials have become a significant source of pollution of air, water, and soil, and has further adverse effects on human health as well as the growth of plant and vegetation. From the viewpoint of the preservation and protection of the global environment, slag recycling has attracted the attention of many scientists in recent years. Foundry slags are generated in the molten and refining processes.

Metallurgical slags have been used for dozens of years with good results, and they have their own loyal users. The EU Directive on Waste (75/442/ETY) defines waste as follows: "Waste" shall mean any substance or object, that the holder discards or intends or is required to discard. In addition to the definition of waste, the European list of wastes (2000/532/EC) can be used to define whether a material is waste or not. Slags from pig iron and the steel industry do not meet the definition of waste, because they have never been discarded from use [1]. Instead, they are sold to consumers as products. Slags from cast iron production very often waste because they are landfilled.

The recycling and utilization of the slags are an attractive alternative in order to reduce and eventually to eliminate disposal costs, minimize related environmental pollution, and save resource conservation [2].

Metallurgical slags from different metallurgical processes are treated and utilized in different ways based on the different slag characteristics. The most economic and efficient option for reducing metallurgical waste generation is through recycling.

Many authors only consider slags from the production of pig iron and steel as metallurgical slags, but the foundry industry specifically uses cast iron and steel for the casting production of melted metal. The most commonly used melting aggregates for steel for castings are electric arc and electric induction furnaces, and a cupola furnace is most suitable for the melting of cast iron.

This paper summarizes the characteristics of different metallurgical slags from the foundry industry and their utilization based on information in the literature and presents the research work carried out by the authors on slags from cast iron steel castings and their utilization in civil engineering. 


\section{SLAGS FROM FOUNDRY PROCESSES}

In the melting process, metal scraps and fluxes (limestone or dolomite) are charged into a furnace, sometimes along with coke for fuel if a blast furnace or cupola furnace is used. Upon heating by the use of electricity (arc furnace, induction furnace) or burning (blast furnace or cupola furnace), scraps are melted into a molten phase. The metal is subsequently gravimetrically separated from the composite flux, leaving the residual slag. Flux is used to adequately render the slag fluid so it can be separated from the molten iron; it then flows freely from the cupola.

Furnace slag is a non-metallic by-product produced in the melting process. It consists primarily of silicates, alumina silicates, and calcium-alumina-silicates. As a by-product of the melting process, furnace slags vary considerably in form depending on the melted metal, furnace type, and slag cooling method used.

The largest quantity of slags from foundry processes are created in cupola furnaces, which are used for cast iron production. An electric arc furnace is usually used for steel production, but it can be used for cast iron production as well. Universal use features an electric induction furnace. In Slovakia, this is used in foundries that produce castings from different materials: cast iron, nodular cast iron, steel, and non-ferrous metals. The slag can also originate by metal treatment in ladle metallurgy (to modify cast iron, steel refining etc.)

\subsection{Slag from electric arc furnace}

An electric arc furnace is primary used for the steelmaking process (steel castings), but it can also be used for cast iron melting (cast iron casting production). The process starts with the charging of various types of steel scrap to the furnace. Next, graphite electrodes are lowered into the furnace. Then, an arc is struck, which causes electricity to travel through the electrodes and the metal itself. The electric arc and the resistance of the metal to this flow of electricity generate the heat.

As the scrap melts, the electrodes are driven deeper through the layers of scrap. In some steel plants, oxygen is also injected through a lance during this process to cut the scrap into smaller sizes.

As the melting process progresses, a pool of liquid steel is generated at the bottom of the furnace. $\mathrm{CaO}$ (in the form of burnt lime or dolomite) is either introduced to the furnace together with the scrap. The steel making process in electric arc furnaces generates up to $150 \mathrm{~kg}$ of slag per ton of steel. Major components of steel slag include Ca-silicates, Ca-Al-ferrites, and the molten oxides of calcium, iron, magnesium, and manganese. Compared to blast furnace slag, steelmaking slag shows a considerably higher content of iron, manganese, and magnesium along with a lower silicon content; i.e., a higher $\mathrm{CaO} / \mathrm{SiO}_{2}$ ratio, ultimately containing almost no sulfur at all.

After tapping the steel from the EAF, the slag is poured into the slag ladle and transported to the slag yard. After solidification and cooling, the slag is crushed in a multi-staged crushing process (from coarse to fine crushing). Each crushing stage is followed by the electromagnetic removal of the metallic portion. The metallic material is returned into the EAF charge. It is necessary to note the pieces of the iron metal contain different portions of slag not removed by crushing.

Demetalized slag is sold mainly to road building companies. By this way, only part of the demetalized slag is utilized; most of it is dumped in a specialized dumping site. The structure of slag consists of di- and tri-calcium silicates together with phosphides, oxidic RO-phases, and calcium ferrites along with calcium sulphide. In contrast to oxygen converter slag, the slag from an EAF has a very small content of free $\mathrm{CaO}$ [3].

Industrial experiments with recycling demetalized EAF slag into the EAF charge showed that the addition of demetalized slag had no negative effects on the smelting process parameters, composition, and cleanness of the produced steel. Additions of demetalized slag enable us to save part of the charged lime. A decrease in charged lime amounts in a ratio of 1 (lime): 2 (demetalized slag) has no negative effect on the dephosphorization process in EAF [3].

Compared to blast furnace slag, EAF slag has more weight, higher hardness and density, is less porous, and is highly resistant to polishing and wear: as such, it is quite suitable for road building [4]. In the past, the application of steel slag was not attractive because of the volumes of blast furnace slag that were available. Slag from steel was used as an artificial fertilizer. Furthermore, it was observed that electric arc furnace (EAF) slag can be used as an inexpensive absorbing agent [5]. Results [6] showed that the properties of ceramic tile produced with added EAF slag (especially its flexural strength), is slightly higher than those of commercial ceramic tile. Overall, EAF slag-enhanced ceramic tile has great potential in the manufacture of high flexural strength or heavy-duty green floor tile, as it is environmental friendly and safe for human health. The final properties of ceramic tile incorporated with EAF slag were found to be comparable with those of commercial ceramic tile and are, therefore, suitable as high flexural strength and heavy-duty green ceramic floor tile.

Steel slag can be used as a natural gravel aggregate substitute in railway embankments [7]. Some very interesting usage options are described in [8,9], where steel slag was utilized in the production of the so-called sea blocks used in artificial cliff building. Steel slags are also used as a ferrous material that is necessary for ferritic concrete production. But steel slag also contains iron droplets that significantly affect the cement mill service life. EAF slag can be used due to its lower lime content; it is very stable and can be used in asphalt without any problem [10].

Substitution of a part of a natural gravel aggregate with demetalized electric arc furnace slag does not have a negative impact on the concrete quality. The final strength characteristics comply with strictcriteria and are suitableeven for the most-demanding applications in the road-building industry [11]; one problem, however, is the need for the execution of steel slag stabilization. Free lime from steel slags has very positive effects on soil $\mathrm{pH}$ adjustment. These 
slags are a very good neutralizing agent and maintain soil pH at neutral levels. In addition, there is an important increase in soil fertility if the slags also contain phosphorus.

Other progressive methods of steel slag utilization appear in the area of the absorption of heavy metals from water [12].

\subsection{Slag from electric induction furnace}

The coreless induction furnace is used when a quick melt of one alloy is desirable, or it is necessary to vary alloys frequently. A coreless furnace is perfect for one-shift operations, as it may be completely emptied and easily restarted. However, induction melting is more sensitive to the quality of the charge materials when compared to a cupola or electric arc furnace, limiting the types of scrap that can be melted. The inherent induction stirring provides excellent metal homogeneity [13].

Slag formation is inevitable during melting. In a coreless induction furnace, slag residuals normally deposit along the refractory walls and within the active power coil. The composition of slag varies with the type of metal being melted in a coreless furnace. The cleanliness of the metallic charge, (consisting of sand-encrusted gates and risers, or rust- and dirt-encrusted scrap) significantly affects the type of slag formed during the melting operation. Because these oxides and non-metallic inclusions are not soluble in molten metal, they float in the liquid metal as an emulsion. This emulsion of slag particles remains stable if the molten metal is continuously agitated, (a result of the magnetic stirring inherent in coreless induction melting). Until the particle size of the nonmetallic inclusions increases to the point where the buoyancy effects countervail the stirring action, the particle will remain suspended. When the flotation effects become great enough, nonmetallic inclusions rise to the surface of the molten metal and agglomerate as a slag. Once the nonmetallic inclusions coalesce into a floating mass on the liquid metal, they can be removed. The use of fluxes accelerates these processes.

When slag makes contact with the hot face of a refractory wall that is colder than the melting point of the slag, the cooling slag will adhere to the lining. This adhering material is called buildup. High-melting point slags are especially prone to promoting buildup. If not prevented from forming or not removed as it forms, buildup will reduce overall efficiency [14].

There is no information about the properties and utilization of slags from induction furnaces in the literature.

\subsection{Slag from cupola furnace}

The cupola furnace is the oldest type of furnace used in foundries. It is very often compared to a blast furnace. Cupolas are used only for melting cast irons. The charge, consisting or iron, coke, flux, and possible alloying elements, is loaded through a charging door located less than halfway up the height of the cupola. The iron is usually a mixture of pig iron and scrap (including risers, runners, and sprues left over from previous castings). Coke is the fuel used to heat the furnace. Forced air is introduced through openings near the bottom of the shell for the combustion of the coke. The flux is a basic compound (such as limestone) that reacts with coke ash and other impurities to form slag. The slag serves to cover the melt, protecting it from reactions with the environment inside the cupola and reducing heat loss. As the mixture is heated and the melting of the iron occurs, the furnace is periodically tapped to provide liquid metal for the pour. As for acid slag, the structural composition of cupola slag is created especially by silicates. The most-frequent minerals are wollastonite $\left(\mathrm{CaO} \cdot \mathrm{SiO}_{2}\right)$, fayalite $\left(2 \mathrm{FeO} \cdot \mathrm{SiO}_{2}\right)$, and other known structural components (especially combinations of $\mathrm{SiO}_{2}-\mathrm{Al}_{2} \mathrm{O}_{3}-\mathrm{CaO}$ ).

The final physical properties of these slags are given not only by their chemical composition but to a great extent by the way in which the molten slag is processed; i.e., cooled down and set. According to the method of cooling down, a reduced or increased crystallization of the particular structural components occurs. The resulting ratio of the crystalline and glassy phase is the major factor influencing their grindability. Their mineralogical composition and size of the crystals influences its resulting strength properties and abrasion resistance. The porosity incurred by leaking gases (the solubility in slag of which it is decreasing during cooling) has a considerable impact on the resistance against frost as well as its strength. Cupola furnace slag is preferably rapidly quenched by submersion into water to yield a fine granulated product, thus reducing the amount of grinding required to make the slag useful in cement. Cupola furnace slag differs from blast furnace slag in chemical composition; for example, cupola slag has a higher silica content and lower calcium oxide content than blast furnace slag. While blast furnaces operate using a basic slag, cupola furnaces generally operate using an acid slag for the production of gray cast iron. Blast furnace operations produce about 30\% slag per ton of molten iron, while cupola furnace operations produce 5 to $6 \%$ lag per ton of iron ore that is melted [15].

\section{UTILIZATION OF SLAG AS BINDER}

Binders are inorganic substances that are usually produced by the heat treatment of natural raw materials of suitable composition. Binders are agents (mixture of substances) that have the ability of self-hardening, thus connecting the granular systems in a rigid compact whole. Into the whole, binders can also accommodate a filler = composite material. Mixing with the desired quantity of water results in a well-workable mass, that subsequently solidifies and hardens.

The substances that are considered as binders are classified as follows [16]:

- direct binders - they react directly with water, which results in solidification and hardening (gypsum, lime, cements).

- latent hydraulic binders - systems (slag, fly ash) that do not solidify and harden with water but only in the presence of activators. The activator can be $\mathrm{CaO}$ or sodium silicate (water glass). 
Cement is a very useful and popular binder in civil engineering. The production of one ton of cement emits approximately one ton of $\mathrm{CO}_{2}$ into the atmosphere. One possible alternative is Alkali Activated Slag concrete, which is a combination of metallurgical furnace slag and an alkaline solution that is used as a binder $[17,18]$.

The most common cementitious materials for an alkali activated slag binder is iron blast-furnace slag; it is the only material to be used worldwide for the production of alkali-activated slag binder. Although other types of slag can also be activated, their activation is not as effective as iron blast-furnace slag, as their hydraulic activity is not as high as iron blast furnace slag [19, 20].

\section{Hydraulicity of slags}

The term "hydraulicity" is derived from the French word "hydraulique" that, at its simplest, is defined as relating to water. It was adopted into construction usage to describe waterproof structures either to convey water or to withstand the ingress of water. The term "hydraulicity" is now used internationally to describe cements and other binders that set and harden as a result of chemical reactions with water and continue to harden even if subsequently placed under water. There are a few exceptions but these chemical reactions generally involve calcium, silica, and aluminum constituents that react with water to form a whole family of calcium silicate and calcium aluminate hydrates [16].

The chemical composition in itself is only a limited guide to the hydraulic properties; the key is in the way the components are combined into the various silicates and aluminates. In 1862, German industrialist Eugen Langen first noticed that ground blast furnace slag showed hydraulic properties, and when in powder form, it solidified when mixed with water. Based on this observation, he decided to use this ground slag as an additive to cement, which took place in Friedrich Wilhelm Work in
Troisdorfe. Slag Portland Cement was created based on his studies. Finding properties of hydraulic slags started a new era of slag utilization $[21,22]$.

Hydraulicity is a property that is typical for materials used in civil engineering. Because the building industry uses a lot of waste materials from metallurgy and from foundries. Quenching in water prevents crystallization and stabilizes a slag's glass properties. Quick quenching is used to maintain a slag's glass properties in order to achieve the latent hydraulic properties with convenient chemical composition. Hydraulicity can be measured by compressive strength [23].

\section{HYDRAULICITY OF SLAGS FROM FOUNDRY PROCESSES}

The main goal of the realized experiments was to compare the hydraulicity of slags from foundry processes with the hydraulicity of blast furnace slag (which is known as the most-common cementitious material for an alkali-activated slag binder). The hydraulicity of the slags was measured by the compressive strength of samples prepared from foundry and blast furnace slag by equal conditions.

\section{Used materials and description of experiments and achieved results}

Different kinds of slags were used in the experiments:

- blast furnace slag - granulated (BFSG),

- blast furnace slag - gravel (BFS),

- cupola furnace slag - gravel (CFS),

- cupola furnace slag - granulated (CFSG),

- slag from electric arc furnace (EAFS).

The chemical composition of the slags is given in Table 1. Figure 1 shows the slags used.

Table 1

Chemical composition of slags used in experiments

\begin{tabular}{|c|c|c|c|c|c|c|c|c|}
\hline \multirow{2}{*}{ Slag } & \multicolumn{8}{|c|}{$\begin{array}{c}\text { Chemical composition, } \\
\%\end{array}$} \\
\hline & $\mathrm{Fe}$ & $\mathrm{FeO}$ & $\mathrm{Fe}_{2} \mathrm{O}_{3}$ & $\mathrm{SiO}_{2}$ & $\mathrm{CaO}$ & Mg0 & $\mathrm{Al}_{2} \mathrm{O}_{3}$ & MnO \\
\hline BFSG & 0.78 & 0.14 & 0.96 & 38.71 & 39.15 & 9.8 & 8.42 & 0.65 \\
\hline BFS & 1.23 & 0.86 & 0.8 & 38.52 & 36.95 & 6.78 & 7.28 & 0.54 \\
\hline CFS & 2.57 & 2.01 & 1.45 & 51.12 & 32.64 & 1.04 & 7.45 & 1.26 \\
\hline CFSG & 2.68 & 2.44 & 1.12 & 45.27 & 24.08 & 5.82 & 9.95 & 0.50 \\
\hline EAFS & 18.82 & 15.09 & 10.18 & 9.36 & 39.42 & 8.61 & 1.96 & 2.99 \\
\hline
\end{tabular}

BFSG - blast furnace slag granulated

BFS - blast furnace slag - gravel

CFS - cupola furnace slag - gravel

CFSG - cupola furnace slag - granulated

EAFS - electric arc furnace slag 
a)

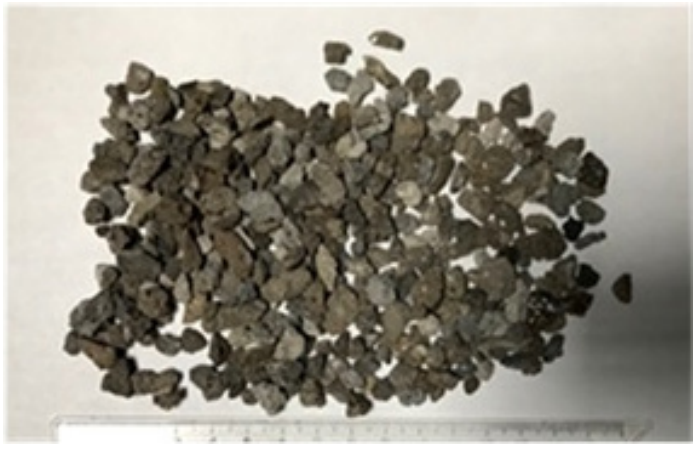

b)



c)

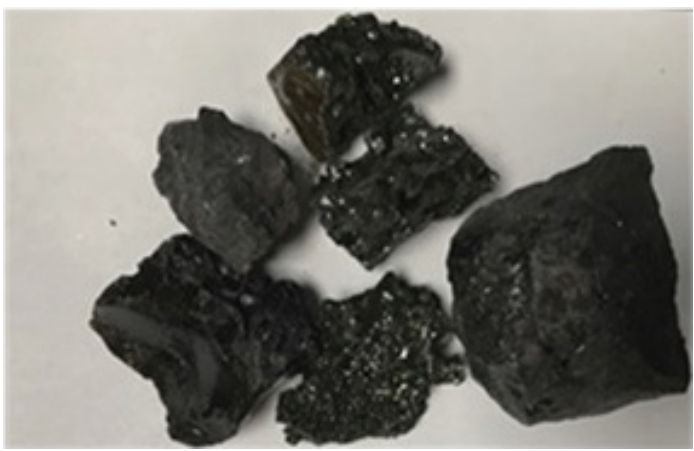

d)

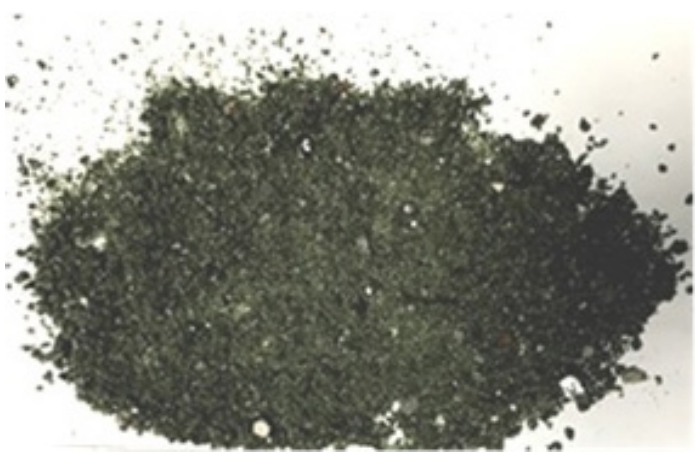

e)

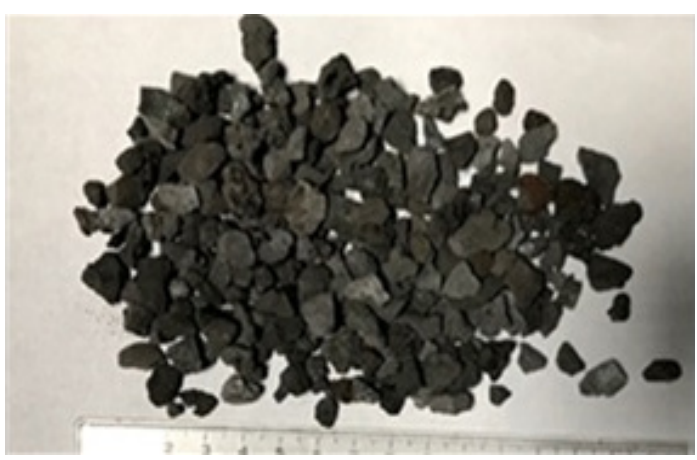

Fig. 1. Slags used in experiments
Slags from cupola furnaces are from two different cast iron foundries. From Foundry A, the solid slag is dumped, and Foundry B granulates the slag (but it is dumped too). The slag from the electric arc furnace is from steel production, and the slags from the blast furnace (gravel and granulated) were used for comparison only because they are the most-common kinds of slags, and their utilization in the civil industry is very widespread.

In the first series of experiments, five kilograms of each fine-ground slags were used for the experimental analyses of hydraulic properties. The mixing of slag and water was carried out by using a wheel mixer for three minutes to reach the best composition and homogeneity for sample production. For the production of samples, a mechanical press was used. The test was conducted on specimens of size $\emptyset 50 \mathrm{~mm}$ and $50 \mathrm{~mm}$ high. Pressed samples were tested from compressive strength immediately, then after 1 and 2 hours, then after 1, 2, and 7 days, and finally after 14, 21, and 28 days. The measured values of the compressive strength of the slags are given in Figure 2.

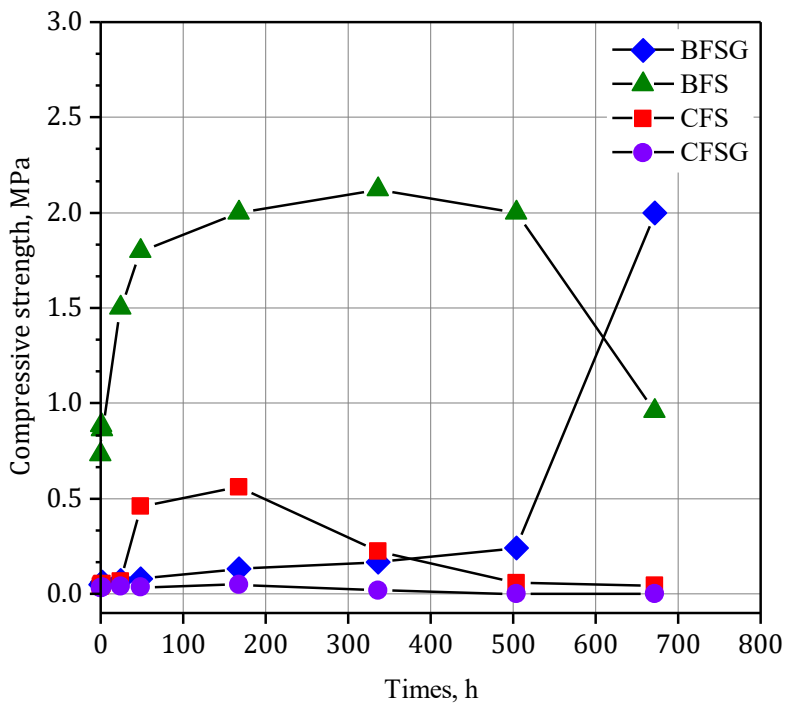

Fig. 2. Measured values of compressive strength of metallurgical slags after different times of hardening

In the sample of blast furnace slag - gravel (BFS), the rising of compressive strength was rapid, and the maximum value of compressive strength was after 14 days; however, after the next 7 days, it dropped to half the value as compared to the situation after 14 days. In the case of granulated blast furnace slag (BFSG), the values of compressive strength increased progressively; the highest value was achieved after 28 days. The values of compressive strength of the slag from the cupola furnace (gravel) increased to 168 hours (7 days) and then started to sink. Its value after seven days was higher than the compressive strength of the granulated blast furnace slag. The worst values of compressive strength were achieved by CFSG - cupola furnace slag granulated. The samples disintegrated after 7 days.

In the second stage of the experiments, the granulated blastfurnaceslag,bothslagsfromthecupolafurnace(gravel and granulated), and the slag from the electric arc furnace were used (their chemical composition is given in Table 1). 
How to follows from previous results, the values of the compressive strength of all slags were very low. The maximum value was 2.2 MPa for blast furnace slag - gravel after 336 hours. The hydraulicity of slag that is expressed by a value of compressive strength can be enhanced by alkaline activating. Therefore, cement in a quantity of 5-50\% was added to the slags. The slags, cement, and water were mixed, and the samples were prepared in the same way as in the first part of the experiments.

The obtained values of the compressive strength of cylinder samples prepared from the mixtures slags and cement in different rations are given in Figure 3. After seven days of hardening, the metallurgical slags had a very low value of compression strength. The lowest value of compression strength was found in the granulated slag from the cupola furnace $(0.05 \mathrm{MPa})$ and the air-cooled cupola furnace slag $(0.56 \mathrm{MPa})$. The compressive strength of blast furnace slag after 7 days was $2 \mathrm{MPa}$. The highest compression strength was achieved by the slag from demetalized slag from the electric arc furnace (2.21 MPa). The addition of cement to slag caused a rise of compression strength in the case of all slags. This impact was most-clear in the case of slag from the electric arc furnace. The addition of $20 \%$ cement to EAFS increased the compressive strength to $10 \mathrm{MPa}$, and EAFS with $40 \%$ cement had a higher compressive strength then pure cement. The influence of cement on the compressive strength of blast furnace slag and cupola furnace slag - gravel was nearly the same. A mixture of $50 \%$ slag (BFS, CFS) and $50 \%$ cement reached a compressive strength of $10 \mathrm{MPa}$.

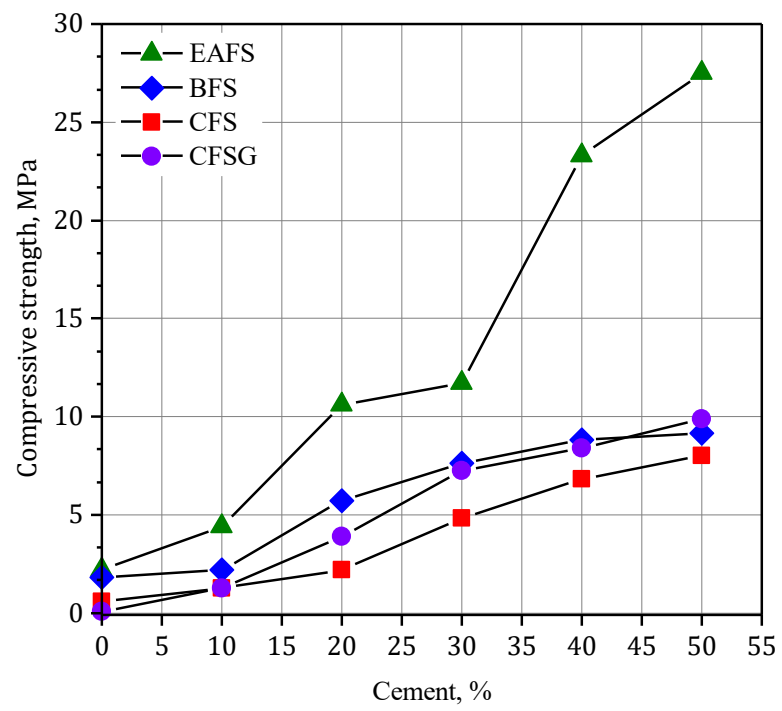

Fig. 3. Influence of cement content on compressive strength of slags

\section{CONCLUSIONS}

Slag is a product of pyrometallurgical processes that are a part of the foundry process. The foundry industry creates cupola furnace slag, electric arc furnace slag, and electro induction furnace slag. These are wastes from the foundry industry. Their ultimate utilization is very low and are usually dumped.
In order to maximize the utilization of slags in other industries, it is very important to know the origin of slag as well as its chemical and mineralogical composition. Slag is a natural product, so its recycling is in harmony with nature. The most-useful utilization of slag is in civil engineering by the production of concrete and cement. Concrete with a high proportion of granulated blast furnace slag is the right material for particularly demanding architecture. The manufacturing of Portland cement is connected with a great deal of carbon dioxide. Cement with a higher proportion of slag means lower carbon dioxide emissions.

The property that influences the binding properties of slag is its hydraulicity, which can be measured by compressive strength. The compressive strength of slags from the foundry process (cupola furnace slag - gravel; cupola furnace slag - granulated; and slag from electric arc furnace) were compared with blast furnace slag. It was very low in all of the slags. The maximum value was $2 \mathrm{MPa}$ for both blast furnace slags. The slags were activated by cement that was added. The compressive strength of pure Portland cement was 16.3 $\mathrm{MPa}$, and higher strengths were only observed by the use of slag from EAF (29.04 MPa). The addition of cement to slag improves the compression strength of all slags. The utilization of slag only as a binder is not possible, but it is possible to replace a portion of the cement with slag. In the case of slags from the electric arc furnace and both slags from the cupola furnace, the compressive strength after seven days achieved its maximum by a composition $80 \%$ cement and $20 \%$ slag. A higher cement content in the mixture caused a decline in compressive strength. This results from the achieved results that the hydraulicity of slag from an electric arc furnace is comparable with cement's hydraulicity. Good hydraulic properties are shown by the slag from the blast furnace. The hydraulic properties of slags from cupola furnaces with up to $50 \%$ cement were comparable with blast furnace slag, but a further rising of cement content in the slag/cement mixture gives rise to fall in the values of the compressive strength of cupola furnace slags.

\section{Acknowledgements}

This work was supported by the Scientific Grant Agency of the Ministry of Education of the Slovak Republic No. VEGA 1/0703/16, VEGA 1/0073/17 and APVV-16-0485.

\section{REFERENCES}

[1] Hami S. (2005). Slag: product or waste - the present situation. Euroslag. Slags - Providing solutions for global construction and other markets. In: $4^{\text {th }}$ European Slag Conference. Proceeding, Euroslag Publication No. 3, 58-68.

[2] Reuter M., Xiao Y. \& Boin U. (2004). Recycling and environmental issues of metallurgical slags and salt fluxes. VII International Conference on Molten Slags Fluxes and Salts, The South African Institute of Mining and Metallurgy, South Africa, Johannesburg, 349-356.

[3] Mihok L., Seilerová K. \& Baricová D. (2004). Recycling of steelmaking slag from electric arc furnace. Archives of Foundry, 13(4), 165-170.

[4] Lewis D.W. (1982). Properties and Uses of Iron and Steel Slags. Symposium on Slag. National Institute for Transport and Road Research, South Africa, 78-88. 
[5] Rastovčan-Mioč A., Sofilič T. \& Mioč B. (2006). Study of Potential Electric Arc Furnace Slag Application. In: Proceedings Book of 7th International Foundrymen Conference. Opatija, 156-162.

[6] Teo P.T., Abu Seman A., Basu P. \& Sharif N.M. (2014). Recycling of Malaysia's electric arc furnace (EAF) slag waste into heavy-duty green ceramic title. Waste Management, 34, 2697-2708.

[7] Merkel T. (2007). New field of application - Steel Slag for Railway Tracks. In: Slag Products - Providing Sustainable Solutions for the Built Environment. 5th European Slag Conference, 19-21 September 2007, Luxembourg. Proceedings, 128-134.

[8] Takahashi T. \& Yabuta K. (2002). Applications for Iron and Steelmaking Slag. NKK Technical Review. No. 87.

[9] Baricová D., Pribulová A., Demeter P., Bul'ko B. \& Rosová A. (2012). Utilizing of the metallurgical slag for production of cementless concrete mixtures. Metalurgija, 42(51), 148-152.

[10] Branca T.A. \& Colla V. Possible uses of steelmaking slag in agriculture: An overview in material recycling - trends and perspectives. Retrieved from www.intechopen.com (accesed 15.08.2017).

[11] Son N.K., Phuoc N.V., Hanh L.T.D., Minh N.H., Son L.M. \& Hoa N.T. (2015). EAF steel slag as supplementary cementing material. Asean Engineering Journal Part B, 2(4), 34-43.

[12] Rex M. (2013). The use of BF, converter and ladle slags in European agriculture - benefits or risks? Slag-providing solutions for global construction and other markets. In: Slag-Providing Solutions for Global Construction and Other Markets. 4th European Slag Conference. 20-21 June 2005, Oulu (Finland). Proceedings, 158-165.

[13] Gandhevar V.R., Bansod S.V. \& Borade A.B. (2011). Induction furnace - a review. International Journal of Engineering and Technology, 4(3), 58-62.

[14] Desmukh M.V. \& Vidhate N.R. (2015). Induction Furnace Slag of Ferrous Foundry. IJSR - International Journal for Scientific Research Development, 2(11), 590-593.
[15] Raju K.V.S.B., Pai Ganesh M., Murthy N., Anirudha K.V. \& Rao P.R. (2010). Geotechnical characterization of miscellaneous wastes. In: GEOtrendz: Proceedings of the Indian geotechnical conference (IGC), II T Bombay, Mumbai, India, December 16-18, 2010, 53-56.

[16] Topinková M. (2015). Inorganic binders (study materials). Ostrava: VŠB -Technical University Ostrava, Faculty of Metallurgy and Materials Engineering.

[17] Hyouk-Seok K., Joo-Won P., Yong-Jun A., Jong-Soo B. \& Choon H. (2011). Activation of ground granulated blast furnace slag cement by calcined alunite. Materials Transaction, 2(52), 210-218.

[18] Böhmer S., Moser G., Neubauer Ch., Peltoniemi M., Schachermayer E., Tesar M., Walter B. \& Winter B. (2008). Aggregates case study. Final Report referring to contract $n^{\circ} 150787-2007$ F1SC-AT. Aggregates case study - data gathering. Vienna, Austria.

[19] Behfarnia K., Shojaci M. \& Mohebi R. (2015). Compressive strength and flexural strength of alkali-activated slag concrete designed by Taguchi method. Asian Journal of Civil Engineering, 4(16), 505-513.

[20] Balaraman R. \& Ligoria S.A. (2015). Utilization of cupola slag in concrete as fine and coarse aggregate. International Journal of Civil Engineering and Technology, 8(6), 6-14.

[21] Slag in history. Retrieved from http://www.nationalslag.org/ slag-history (accesed 10.07.2017).

[22] Laakri M., Oudjit M.N. \& Abdeli K. (2014). Volumetric Variation and Rheology of Cement Based Mineral Additions (Blast Furnace Slag and Silica Fume). Journal of Civil Engineering and Architecture, 2(8), 207-212.

[23] Livesey P. Hydraulicity. Retrieved from http://www: buildingconservation.com/articles/hydrau-licity/hydraulicity.htm (accesed 15.08.2017) 